\section{Root-zone Medium Influences Growth of Poinsettias Treated with Paclobutrazol- impregnated Spikes and Drenches}

\author{
Steven E. Newman ${ }^{1}$ and Jeffrey S. Tant ${ }^{2}$ \\ Department of Plant and Soil Sciences, Mississippi Agricultural and Forestry \\ Experiment Station, Box 9555, Mississippi State, MS 39762
}

Additional index words. cultural practices, plant growth regulators, greenhouse production, Euphorbia pulcherrima

\begin{abstract}
An experiment was conducted to determine the influence of eight commercial root-zone media (four peat based and four pine bark based) on the effects of paclobutrazol applied to Euphorbia pulcherrima Willd. 'Eckespoint Celebrate 2' as an impregnated spike or a drench. Paclobutrazol treatments had the least influence on stem elongation of poinsettias grown in the peat-based medium containing Bacctite, a compressed peat product designed to increase aeration and cation exchange capacity, or composted pine bark ground to a particle size that could pass through an opening $1 \mathrm{~cm}$ or smaller. Spikes were more effective at reducing shoot elongation than drenches. Spike treatments also resulted in lower bract dry-matter accumulation than drenches. Paclobutrazol applied as a spike to poinsettias at pinch could combine pinching and chemical growth regulator application into one simultaneous operation. Chemical name used: $( \pm)-\left(R^{*}, R^{*}\right)$-beta- $[(4-$ chlorophenyl)methyl]-alpha-(1,1,-dimethyl)-1H-1,2,4,-triazole-1-ethanol (paclobutrazol).
\end{abstract}

Modern poinsettia cultivars are longer lasting and shorter than cultivars popular 20 years ago. Despite the development of shorter cultivars, the control of plant height is still an important task in high-quality poinsettia production. Most cultivars would not meet the prescribed height or size requirements without cultural practices to regulate growth (Hartley, 1992). Berghage and Heins (1991) have shown that diurnal temperature manipulation is effective in regulating stem elongation of poinsettias, but most growers still use some chemical growth regulators to control poinsettia height (Hartley, 1992).

Paclobutrazol, a triazole plant growth regulator, is effective on poinsettias as either a spray or a drench (Barrett, 1982); however, these methods require precision to apply small amounts of chemical. In previous studies with

Received for publication 15 June 1995. Accepted for publication 22 Sept. 1995. Mississippi Agricultural and Forestry Expt. Sta. Journal Series J-8710. This study was funded by Hatch Project MIS-1326 and was conducted in partial completion of the MS degree. Thanks are extended to Allan Oswalt of the Michigan Peat Co., Terry Wilbourn of the O.M. Scott Co., Sheron McIntire of the Uniroyal Co., and David Hartley of the Paul Ecke Poinsettia Ranch, who provided the media, fertilizer, growth regulators, and plant material used in this study. Use of trade names does not imply endorsement of the products named nor criticism of similar ones not named. The cost of publishing this paper was defrayed in part by the payment of page charges. Under postal regulations, this paper therefore must be hereby marked advertisement solely to indicate this fact.

${ }^{1}$ Associate Professor. Current address to which reprint requests should be sent: Dept. of Horticulture and Landscape Architecture, Colorado State Univ., Ft. Collins, CO 80523-1173.

${ }^{2}$ Former Graduate Student. paclobutrazol, the base organic material of the medium has influenced the activity of the growth regulator (Barrett, 1982; Lamont, 1986). When pine bark is used as a primary medium component, the effectiveness of $\alpha$ cyclopropyl-( $p$-methoxy phenyl)-5 pyrimidinemethanol (ancymidol) drenches is reduced (Barrett, 1982; Bonaminio and Larson, 1978; Tschabold et al., 1975). Paclobutrazol, which differs in chemical structure from ancymidol, also is inadequately effective in pine bark media (Barrett, 1982). Because of the wide variety of container media used by greenhouse growers and the effect of these media on plant growth regulator activity, we initiated this study to determine the relative efficacy of paclobutrazol on poinsettias when applied as an impregnated spike or drench to eight commercial media (four pine bark based and four peat based). communication).

${ }^{" M} 366$ = Metro-mix 366 (O.M. Scotts Co.; Cat. Sheet H4914).

${ }^{\mathrm{t}} \mathrm{M} 700=$ Metro-mix 700 (O.M. Scotts Co.; Cat. Sheet H4919).

${ }^{\mathrm{s}}$ Coarse-grind composted pine bark (0- to $1.6-\mathrm{cm}$ pieces).

${ }^{\mathrm{r}}$ M702 = Metro-mix 702 (O.M. Scotts Co.; Cat. Sheet H4919).

${ }^{q}$ Fine-grind composted pine bark ( 0 - to $1-\mathrm{cm}$ pieces).
Rooted cuttings of poinsettia 'Eckespoint Celebrate 2' were potted into 1.5-liter $(15 \mathrm{~cm})$ azalea pots on $20 \mathrm{Aug}$. 1992. We used four pine-bark-based and four peat-based media (Table 1). The former included Metro 360 (M360), Metro 366 (M366), Metro 700 (M700), and Metro 702 (M702) (Metro-Mix, O.M. Scott, Marysville, Ohio), and the peatbased media were Baccto Grower's Mix (BG), Baccto High Porosity Professional Mix (HP), Baccto High Porosity Professional Mix with Bacctite (HPB), and Baccto Rockwool Mix (RW) (Baccto, Michigan Peat Co., Houston). Liquid fertilizer (15N-2.2P-12.5K) (Peter's Excel, Cal/Mag; O.M. Scott, Marysville, Ohio) was applied at $300 \mathrm{mg} \mathrm{N} /$ liter with each irrigation and was terminated 3 weeks before the end of the study. All plants were pinched on 3 Sept. 1992, leaving five to seven nodes. The plants were grown in a double-polyethylenecovered greenhouse with a heating setpoint of $20 \mathrm{C}$ and a cooling setpoint of $28 \mathrm{C}$ under natural daylength.

Paclobutrazol applications consisted of eight spike and two drench treatments. Spikes were inserted on 4 Sept. 1992, 1 day after pinch. Drenches were applied on 17 Sept. 1992 at 0.25 or $1.0 \mathrm{mg}$ a.i./pot in $250 \mathrm{ml}$ tap water 2 weeks after pinch, when the axillary shoots were $5 \mathrm{~cm}$ long. The 5 -cm $\times 6-\mathrm{mm}$ spikes were similar to Jobe Fertilizer Spikes (Weatherly Consumer Products, Lexington, Ky.) but without fertilizer. The paclobutrazol concentration in the spikes was $0.0625,0.25$, 0.50 , or $1 \mathrm{mg}$ a.i./spike. We inserted either 0 , $1,2,4,6$, or 8 spikes into each pot, resulting in treatment rates of $0,0.125,0.250,0.375,0.500$, or $1.0 \mathrm{mg}$ a.i./pot. All spikes were inserted completely into the root medium $2.5 \mathrm{~cm}$ from the stem of the plant. In treatments with more than one spike, spikes were inserted equidistant from one another around the plant. Shoot length (length of shoots when excised at the original break) and bract dry weight were recorded 108 days after pinch (20 Dec. 1992). The experiment was conducted as a split-plot design with five replications. Root media were

Table 1. Composition of pine-bark-based and peatmoss-based media.

\begin{tabular}{lccccccc}
\hline & \multicolumn{7}{c}{ Vol $(\%)$} \\
\cline { 2 - 7 } Medium & Peatmoss & Vermiculite & Perlite & Bark ash & Pine bark & Rockwool & Bacctite \\
\hline BG $^{z}$ & 67 & 25 & 8 & 0 & 0 & 0 & 0 \\
HP $^{y}$ & 59 & 7 & 24 & 0 & 0 & 10 & 0 \\
HPB $^{\mathrm{y}}$ & 50 & 5 & 18 & 0 & 0 & 7 & 20 \\
RW $^{\mathrm{w}}$ & 60 & 0 & 0 & 0 & 0 & 40 & 0 \\
M360 $^{\mathrm{v}}$ & $31-45$ & $37-47$ & 0 & $12-15$ & 0 & 0 & 0 \\
M366 $^{\mathrm{u}}$ & $35-45$ & $30-40$ & 0 & 5 & $20-30$ & 0 & 0 \\
M700 $^{\mathrm{t}}$ & $15-25$ & $10-15$ & $5-15$ & 0 & $50-60^{\mathrm{s}}$ & 0 & 0 \\
M702 & $15-25$ & $10-15$ & $5-15$ & 0 & $50-60^{\mathrm{q}}$ & 0 & 0
\end{tabular}

${ }^{2} \mathrm{BG}=$ Baccto Growers Mix (Michigan Peat Co., Houston; Tech. Bul. TB-301).

${ }^{\mathrm{y}} \mathrm{HP}=$ Baccto High Porosity Professional (Michigan Peat Co.; Tech. Bul. TB-304).

${ }^{x} \mathrm{HPB}=$ High Porosity Professional with Bacctite (Allan Oswalt, Michigan Peat Co., Houston, personal

${ }^{w}$ RW = Baccto Rockwool Mix (Allan Oswalt, Michigan Peat Co., personal communication).

${ }^{\vee}$ M360 = Metro-mix 360 (O.M. Scotts Co., Marysville, Ohio; Cat. Sheet H4912). 
the whole plots, and paclobutrazol concentrations were applied randomly within each whole plot. Preplanned comparisons made between the spike counts within media were conducted by Tukey's honest significant difference at $P \leq 0.05$ using the experiment-wise error rate. Regression analyses were conducted using general linear models (SAS Institute, Cary, N.C.).

\section{Results}

Paclobutrazol spikes were more effective than drench applications in reducing shoot elongation in all media (Table 2). At $0.25 \mathrm{mg} /$ pot, four spikes were more effective than one in reducing stem elongation for plants grown in BG, HP, HPB, or M360; whereas one spike was more effective than four in reducing stem elongation of plants in RW, M700, and M702. At $0.5 \mathrm{mg} / \mathrm{pot}$, eight spikes were more effec- tive than two in controlling stem elongation for plants grown in $\mathrm{HPB}, \mathrm{RW}$, and M702; whereas for BG only, two spikes were more effective than eight. Poinsettias not treated with paclobutrazol were shorter when grown in peat-based rather than in bark-based media (Table 2). On average, paclobutrazol applied as a drench reduced stem elongation for plants grown in HPB 27\%, M702 36\%, HP 39\%, BG $44 \%, \mathrm{M} 36646 \%, \mathrm{M} 36047 \%, \mathrm{M} 70051 \%$, and RW 55\% relative to control plants. On average, paclobutrazol applied as an impregnated spike reduced stem elongation for plants grown in M702 46\%, HPB 48\%, BG 55\%, RW 56\%, HP 58\%, M700 60\%, M360 64\%, and M366 $68 \%$ relative to control plants.

Poinsettias grown in bark-based media and RW produced more bract dry weight than poinsettias in peat-based media (Table 3 ). At $0.25 \mathrm{mg} / \mathrm{pot}$, four spikes were more effective than one in reducing bract dry-weight accu- mulation of plants grown in HP, HPB, M360, and M700; whereas one spike was more effective than four for BG, RW, and M702 (Table 3). At $0.5 \mathrm{mg} / \mathrm{pot}$, eight spikes were more effective than two in reducing bract dry-weight accumulation for plants grown in HP, HPB, $\mathrm{RW}$, and M702; whereas for BG only, two spikes were more effective than eight (Table $3)$. Bract dry weight of paclobutrazol-treated plants tended to be higher on plants grown in peat-based media compared to those grown in pine bark. On average, paclobutrazol applied as a drench reduced bract weight accumulation for plants grown in HP 10\%, HPB 23\%, BG 32\%, M360 34\%, M702 36\%, M70043\%, RW 49\%, and M366 50\% relative to controls. Similarly, paclobutrazol applied as an impregnated spike reduced bract weight accumulation for plants grown in BG 30\%, HPB and RW 49\%, HP 50\%, M702 51\%, M700 53\%, M360 59\%, and M366 63\%.

Table 2. Effect of peat- and pine-bark-based root medium, paclobutrazol delivery method and concentration on stem length of 'Eckespoint Celebrate 2' poinsettias 108 days after pinch.

\begin{tabular}{|c|c|c|c|c|c|c|c|c|c|c|}
\hline \multirow{2}{*}{\multicolumn{3}{|c|}{ Paclobutrazol application }} & \multicolumn{8}{|c|}{ Stem length $(\mathrm{cm})$} \\
\hline & & & \multicolumn{8}{|c|}{ Root medium } \\
\hline Type & (mg a.i./spike) & (mg a.i./pot) & $\mathrm{BG}^{\mathrm{z}}$ & $\mathrm{HP}^{\mathrm{z}}$ & $\mathrm{HPB}^{\mathrm{z}}$ & $\mathrm{RW}^{\mathrm{z}}$ & M360 & M366 & M700y & M702y \\
\hline None & & 0 & 16.5 & 15.5 & 14.1 & 20.7 & 22.3 & 23.5 & 26.2 & 20.4 \\
\hline Drench & & 0.25 & 9.6 & 10.9 & 11.0 & 10.3 & 13.6 & 13.4 & 13.6 & 13.5 \\
\hline Spikes & & 0.5 & 8.7 & 8.1 & 9.6 & 8.1 & 10.0 & 11.3 & 11.7 & 12.8 \\
\hline Two & 0.0625 & 0.125 & 9.6 & 8.4 & 10.7 & 12.7 & 10.1 & 10.7 & 15.4 & 15.7 \\
\hline One & 0.250 & 0.25 & 7.8 & 8.4 & 8.8 & 9.0 & 11.1 & 9.1 & 10.1 & 10.9 \\
\hline Four & 0.0625 & 0.25 & 7.3 & 6.4 & 7.4 & 9.9 & 9.0 & 8.7 & 11.2 & 13.3 \\
\hline Six & 0.0625 & 0.375 & 7.2 & 6.3 & 5.8 & 9.2 & 6.9 & 5.9 & 10.8 & 7.7 \\
\hline Two & 0.250 & 0.5 & 5.9 & 5.1 & 6.8 & 8.6 & 6.3 & 6.4 & 9.2 & 10.7 \\
\hline Eight & 0.0625 & 0.5 & 6.9 & 5.2 & 6.2 & 7.0 & 6.6 & 6.5 & 9.2 & 9.9 \\
\hline One & 1.00 & 1 & 7.0 & 5.6 & 5.8 & 7.6 & 6.1 & 5.9 & 7.4 & 8.6 \\
\hline \multicolumn{11}{|c|}{ Analysis of variance } \\
\hline Media & & 0.0001 & & & & & & & & \\
\hline Delive & & 0.0001 & & & & & & & & \\
\hline Media & & 0.0001 & & & & & & & & \\
\hline \multicolumn{11}{|c|}{ Regression on rate } \\
\hline Line & & & $* * * *$ & $* * * *$ & $* * * *$ & $* * * *$ & $* * * *$ & $* * * *$ & $* * * *$ & $* * * *$ \\
\hline Quac & & & $* * * *$ & $* * * *$ & $* * *$ & $* * * *$ & $* * * *$ & $* * * *$ & $* * * *$ & $* * * *$ \\
\hline Tukey's & & 0.49 & & & & & & & & \\
\hline
\end{tabular}

${ }^{\mathrm{z}} \mathrm{BG}=$ Baccto Growers Mix, HP = Baccto High Porosity Professional, HPB = High Porosity Professional with Bacctite, and RW = Baccto Rockwool Mix. yM360 = Metro-mix 360, M366 = Metro-mix 366, M700 = Metro-mix 700, and M702 = Metro-mix 702.

Table 3. Effect of peat- and pine-bark-based root medium, paclobutrazol delivery method and concentration on bract dry weight of 'Eckespoint Celebrate 2' poinsettias 108 days after pinch.

\begin{tabular}{|c|c|c|c|c|c|c|c|c|c|c|}
\hline & & & \multicolumn{8}{|c|}{ Stem length $(\mathrm{cm})$} \\
\hline \multicolumn{3}{|c|}{ Paclobutrazol application } & \multicolumn{8}{|c|}{ Root medium } \\
\hline Type & (mg a.i./spike) & (mg a.i./pot) & $\mathrm{BG}^{\mathrm{z}}$ & $\mathrm{HP}^{\mathrm{z}}$ & $\mathrm{HPB}^{\mathrm{z}}$ & $\mathrm{RW}^{\mathrm{z}}$ & M360 y & M366 & M700 ${ }^{y}$ & M702 \\
\hline None & & 0 & 6.4 & 7.2 & 5.6 & 10.9 & 12.2 & 9.9 & 11.8 & 9.6 \\
\hline Drench & & 0.25 & 4.7 & 6.8 & 4.8 & 6.2 & 8.3 & 4.7 & 8.2 & 6.3 \\
\hline Spikes & & 0.5 & 3.9 & 6.2 & 3.9 & 4.8 & 7.8 & 5.2 & 6.7 & 6.2 \\
\hline Two & 0.0625 & 0.125 & 6.0 & 3.6 & 3.0 & 8.1 & 6.4 & 5.0 & 8.4 & 7.0 \\
\hline One & 0.250 & 0.25 & 3.8 & 5.6 & 3.8 & 5.1 & 6.5 & 4.3 & 5.6 & 4.4 \\
\hline Four & 0.0625 & 0.25 & 4.9 & 3.8 & 3.2 & 6.0 & 5.7 & 4.1 & 5.1 & 4.8 \\
\hline Six & 0.0625 & 0.375 & 5.2 & 3.4 & 2.4 & 5.9 & 4.6 & 2.7 & 5.1 & 2.8 \\
\hline Two & 0.250 & 0.5 & 3.1 & 3.3 & 3.7 & 5.4 & 4.0 & 2.9 & 4.9 & 5.6 \\
\hline Eight & 0.0625 & 0.5 & 4.5 & 2.3 & 1.8 & 4.0 & 3.8 & 3.7 & 4.6 & 4.1 \\
\hline One & 1.00 & 1 & 4.1 & 3.5 & 2.4 & 4.6 & 4.2 & 2.7 & 4.7 & 4.4 \\
\hline \multicolumn{11}{|c|}{ Analysis of variance } \\
\hline Media & & 0.0001 & & & & & & & & \\
\hline Delive & & 0.0001 & & & & & & & & \\
\hline Media & & 0.0001 & & & & & & & & \\
\hline \multicolumn{11}{|c|}{ Regression on rate } \\
\hline Line & & & $* *$ & $*$ & $* *$ & $* * * *$ & $* * * *$ & $* * * *$ & $* * * *$ & $* * * *$ \\
\hline Qua & & & NS & $* *$ & $* *$ & $* *$ & $* * *$ & $* * * *$ & $* * * *$ & $* * * *$ \\
\hline Tukey's & & 0.49 & & & & & & & & \\
\hline
\end{tabular}

${ }^{2} \mathrm{BG}=$ Baccto Growers Mix, HP = Baccto High Porosity Professional, HPB = High Porosity Professional with Bacctite, and RW = Baccto Rockwool Mix.

y M360 = Metro-mix 360, M366 = Metro-mix 366, M700 = Metro-mix 700, and M702 = Metro-mix 702. 


\section{Discussion}

Poinsettias treated with paclobutrazol, as a percentage of the controls, were taller when grown in HPB and M702. HPB is a professional, high-porosity, peat-based medium to which the manufacturers added a proprietary compressed peat product, Bacctite. The purpose of this product is to improve aeration and contribute to the total cation exchange matrix of the medium. HPB also had the lowest volume of peatmoss of the peat-based media studied. M700 and M702 had the highest volume of composted pine bark of the bark-based media studied. The only difference between M700 and M702 was the particle size of the bark. The bark of M702 was ground to pass through a $1-\mathrm{cm}$ opening, whereas M700 was ground to pass through a $1.6-\mathrm{cm}$ opening, which resulted in a smaller particle and more surface area of the bark for M702. When pine bark is used as a primary medium component, ancymidol drenches had limited effectiveness (Barrett, 1982; Bonaminio and Larson, 1978; Murray, 1982; Tschabold et al., 1975). Paclobutrazol also has had limited effectiveness in pine bark media (Barrett, 1982). Paclobutrazol binds to the bark and is obtainable by the plant; however, it remains concentrated in the upper levels of a container, above most roots (Bonaminio and Larson, 1975).

Paclobutrazol applied to poinsettias using impregnated spikes was as or more effective in controlling plant height than paclobutrazol applied as a drench. Poinsettias are often pinched 2 weeks after transplant, and chemical growth regulators are often applied when the subsequent breaks are 2- to 3-cmlong (Hartley,
1992). Paclobutrazol applied as a spike to poinsettias at pinch would combine two procedures into one handling step, potentially reducing labor costs. Preplant incorporation of $(E)-(+)-(S)-1-(4-c h l o r o p h e n y 1)-4,4-$ dimethyl-2-(1,2,4-triazol-1-yl)-pent-1-ene-3ol (uniconazole), a growth regulator similar to paclobutrazol, resulted in commercially acceptable height control of Easter lilies (Lilium longiflorum Thunb.) without delaying anthesis (McAvoy, 1991). Barrett et al. (1994) found paclobutrazol spike applications to be as effective as drenches for several species; whereas Sanderson et al. (1988) found paclobutrazol tablets and gels to be less effective in controlling poinsettia growth than drench treatments. In this study, paclobutrazol impregnated spikes were inserted at pinch, whereas paclobutrazol drenches were applied 2 weeks after pinch. Therefore, spike-treated plants were exposed to paclobutrazol for a longer period than drench-treated plants, and this difference may account for the discrepancies between our work and that of Barrett et al. (1994).

More paclobutrazol impregnated spikes in the medium provided more available product for uptake by roots, as shown by shorter plant stems with several spikes compared to plants with single spikes, except in the RW, M700, and M702 media. The M700 and M702 media had the largest volume of bark, which has a high affinity for triazole plant growth regulators (Barrett et al., 1994) and, thus, may have affected this response. Due to the effectiveness of the spikes, a lower amount of chemical can be applied to achieve results equal to drench applications. Application of paclobutrazol as a spike during pinching or spacing potentially could eliminate a handling step for poinsettia production, precision of the application would be increased, and a lesser-skilled employee could apply the growth regulator.

\section{Literature Cited}

Barrett, J.E. 1982. Chrysanthemum height control by ancymidol, PP333, and EL-500 dependent on medium composition. HortScience 17:737-738.

Barrett, J.E., C.A. Bartuska, and T.A. Nell. 1994. Comparison of paclobutrazol drench and spike applications for height control of potted floriculture crops. HortScience 29:180-182.

Berghage, R.D. and R.D. Heins. 1991. Quantification of temperature effects on stem elongation in poinsettia. J. Amer. Soc. Hort. Sci. 116:14-18.

Bonaminio, V.P. and R.A. Larson. 1978. Influences of potting media, temperature, and concentration of ancymidol on growth of Chrysanthemum morifolium Ramat. J. Amer. Soc. Hort. Sci. 103:752-756.

Hartley, D.E. 1992. Poinsettias, p. 306-331. In R.A. Larson (ed.). Introduction to floriculture. Academic, San Diego, Calif.

Lamont, G.P. 1986. Evaluation of growth retardants for controlling plant height of Geraldton wax flowers (Chamelaucium uncinatum Schauer.). Scientia Hort. 29:363-371.

McAvoy, R.J. 1991. Response of Easter lily to preplant incorporation of uniconazole into the planting medium. HortScience 26:152-154.

Murray, G.E. 1982. The effect of granular ancymidol on selected bedding plants. MS Thesis, Auburn Univ., Auburn, Ala.

Sanderson, K.C., W.C. Martin, Jr., and J. McGuire. 1988. Comparison of paclobutrazol tablets, drenches, gels, capsules, and sprays on chrysanthemum growth. HortScience 23:1008-1009.

Tschabold, E.E., W.C. Meredith, L.R. Guse, and E.V. Krumkalns. 1975. Ancymidol performance as altered by potting media composition. J. Amer. Soc. Hort. Sci. 100:142-144. 